\title{
ACRL Elections and Appointments
}

Evan Ira Farber, librarian, Earlham College, was elected vice chairman and chairman-elect of the College Libraries Section of ACRL, and Jean P. Black, librarian, Portland (Ore.) State College, was elected secretary. Lynn D. Bartlett, director of educational resources in Oakland Community College, Bloomfield Hills, Mich., was chosen by the Junior College Libraries Section as vice chairman and chairmanelect and Mrs. Ruth E. Riggs, library director, Middlesex County College, Edison, N.J., was chosen as secretary. New officers of the Rare Books Section are J. M. Edelstein, humanities bibliographer, university research library, UCLA, vice chairman and chairman-elect; and Howell J. Heaney, bibliographer, free library of Philadelphia, secretary. Members of the Subject Specialists Section elected Thomas D. Gillies, assistant director, Linda Hall library, as vice chairman and chairman-elect; Mrs. Lois Fern, reference librarian, United States Information Agency, Washington, D.C., was elected secretary for $1967 / 70$. G. F. Shepherd, Jr., associate director, Cornell University, is the vice chairman and chairman-elect of the University Libraries Section.

\section{Subsection Officers}

The Agriculture and Biological Sciences Subsection of the Subject Specialists Section named Louise Darling, biomedical librarian, center for health sciences in UCLA as vice chairman and chairman-elect; secretary is Mrs. Blanche Oliveri, assistant director for program coordination services, National Agricultural Iibrary; the new vice chairman and chairmanelect of the Art Subsection is Herbert C. Scherer, art librarian, University of Minnesota, Minneapolis; and secretary for 1967/69 is Nancy L. Johanson, assistant, art department, Minneapolis public library. Morris L. Cohen, librarian, Biddle law library, University of Pennsylvania, Philadelphia, was chosen by members of the Law and Political Science Subsection as vice chairman and chairman-elect; Mr. Cohen will act as chairman this year because of the resignation of Kurt Schwerin, who was chosen as last year's chairman-elect. Hugh Montgomery, university librarian, University of Massachusetts, is the new secretary of the subsection. Robert R. McClarren, director, Indiana state library, is member-at-large for the subsection. Vice chairman and chairman-elect of the Slavic and East European Subsection is Dmytro Shtohyrn, head Slavic cataloger, University of Illinois, Urbana; member-at-large is Peter A. Goy, assistant librarian, City College of the City University of New York.

\section{ACRL Committee Chathmen}

Committee on Appointments (1967) and Nominations (1968): Ben Bowman, chairman, library department, Hunter College, New York 10021.

Audio Visual Committee: Albert P. Marshall, librarian, Lincoln University, Jefferson City, Mo. 65101 .

Committee on Community Use of Academic Libraries: E. J. Josey, academic and research libraries consultant, New York State library, Albany 12224.

Executive Committee: James Humphrey, III. chief librarian, Metropolitan Museum of Art, New York 10028 (ex officio).

Advisory Committee on Cooperation with Educational and Professional Organizations: John P. McDonald, director of libraries, University of Connecticut, Storrs 06268.

Committee on Grants: H. Vail Deale, director of libraries, Beloit College, Beloit, Wis. 53512.

International Relations Committee: Thomas R. Buckman, director of libraries, University of Kansas, Lawrence 66044.

Legislation Committee: John H. Moriarty, director of libraries and audio-visual center, Purdue University, Lafayette, Ind. 47907.

Committee on Liaison with Accrediting Agencies: Anne C. Edmonds, librarian, Mount Holyoke College, South Hadley, Mass. 01075.

Committee on Library Surveys: Edwin E. Williams, associate university librarian, Harvard University, Cambridge, Mass. 02138.

Local Arrangements Committee: Kenneth J. LaBudde, director of libraries, University of Missouri at Kansas City 64110.

National Library Week Committee: Mrs. Mina E. Hoyer, head librarian, Miami University, Middletown, Ohio 45042.

Planning and Action Committee: David Kaser, director, Joint University Libraries, Nashville 37203 (ex officio).

Publications Committee: Mark M. Gormley, director of libraries, University of Wisconsin-Milwaukee, 53211.

Ad Hoc Committee on Relations with ARL: Gustave A. Harrer, director of libraries, Boston University, 02215.

Committee on Standards: Norman E. Tanis, director of the library, Kansas State College of Pittsburg, 66762.

Ad Hoc Subcommittee on Revision of Junior College Library Standards: James O. Wallace, director of library services. San Antonio College, San Antonio, Tex. 78212.

Ad Hoc Subcommittee to Consider Possible University Library Standards: Ellsworth (Continued on page 160) 


\section{TITLE II ORDERS}

Taylor-Carlisle is now accepting orders under the Title II

Progran, which will be billed, shipped and dated as per your specifications.

Our liberal discount policy applies to all orders.

Address all Title II orders and correspondence to:

Title II

\section{Taylor-Carlisle}

115 East 23rd St., New York, N.Y. 10010

or to

Title II

Florida's Taylor-Carlisle

Winter Park Mall, Winter Park, Florida 


\section{ACRL ELECTIONS}

(Continued from page 158)

Mason, director of library services, Hofstra University, Hempstead, L.I., N.Y. 11550.

Editorial Board, Choice: Sister Helen, librarian, Trinity College, Washington, D.C. 20017 ; Editor, Peter Doiron, 100 Riverview Center, Middletown, Conn. 06457.

\section{Are YOU \\ a member \\ of ALA?}

Join for 1967 !

Write:

Membership Promotion

American Library Association

50 East Huron Street

Chicago, Illinois 60611

\section{"CONFIDENCE" In Our Complete Periodicals Service}

-American or foreign. All periodicals, handled with a degree of accuracy second to none! Write for our Brochure-then ASK FOR REFERENCES from any one of the hundreds of Librarians taking ad. vantages of our outstanding and accepted procedures. Send your list and ask for a quotation and recommendations.

"Promptness Is A Tradition With McGregor"

-and Promptness is a mark of Experience, Trained Personnel, Ample Facilities, Proper Working Space, Financial Stability, Responsible Management, Completeness of Service, and Efficiency.

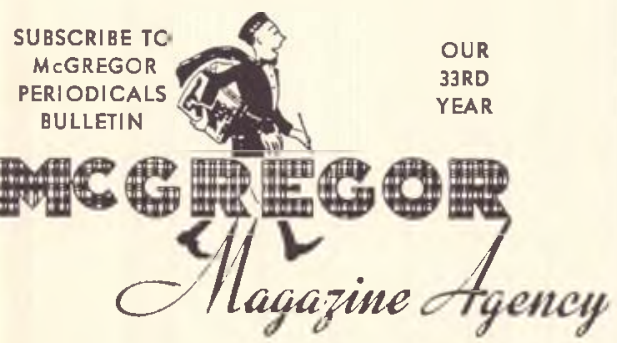

Mount Morris, Illinois 61054
College \& Research Libraries, Editor, David Kaser, director, Joint University libraries, Nashville 37203.

ACRL Microcard Series, Editor, Mrs. Margaret Toth, Rush Rhees library, University of Rochester, Rochester, N.Y. 14627.

ACRL Monograph Series, Editor, David W. Heron, director of libraries, University of Nevada, Reno 89507.

ACRL Representative on ALA Membership Committee: Frances Kennedy, librarian, Oklahoma City University, Oklahoma City, Okla. 73106.

AAJC-ALA (ACRL Committee on Junior College Libraries: Staff Liaison, William G. Shannon, assistant executive director, American Association of Junior Colleges, Washington, D.C. 20036; George M. Bailey, ACRL executive secretary, Chicago 60611.

Association of American Colleges-ACRL Committee on College Libraries: Chairman: Branford P. Millar, president, Portland State College, Portland, Ore. 97207; Staff Representatives, George M. Bailey, ACRL executive secretary, Chicago 60611; F. L. Wormald, vice president, Association of American Colleges, Washington, D.C. 20009.

\section{URBAN INFORMATION RETRIEVAL}

An information retrieval system that scans microfilm documents and automatically selects those with desired subject matter, is now operational in the library of the Center for Urban Regionalism, Kent State University. The system will (I) gather existing urban information and research data especially useful for planners; (2) abstract this information if necessary; (3) index each document according to key words or phrases from an "urban thesaurus"; and (4) microfilm each abstract along with its access codes. The "urban thesaurus" is a 20,000 key word-phrase index compiled by John E. Rickert, associate director of the center. The system will receive contributed information from all over the country. Future users of the system also will most likely add their own data to the system's coded microfilm library, and the system permits continuous updating of both the thesaurus and the microfilm library.

Rose L. Vormelker, who compiled the mass of regional information in conjunction with the Community Research Conference, has been appointed chief of the Urban Library and Information Service at Kent State to organize the urban data.

Development of the thesaurus with the Recordak System and organizing the information was made possible by a $\$ 32,943$ federal grant from the U.S. Department of Housing and Urban Development. 